\title{
MEDIA WARAGA SEBAGAI UPAYA MENINGKATKAN KEMAMPUAN SISWA SEKOLAH DASAR DALAM MENGIDENTIFIKASI KERAGAMAN BUDAYA
}

\author{
Saktia Alifa, Imaniar Purbasari, dan Ristiyani
}

Universitas Muria Kudus

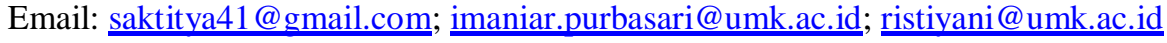

\section{Info Artikel}

Sejarah Artikel:

Diserahkan 30 Juli 2020

Direvisi 12 Agustus 2020

Disetujui 14 Agustus 2020

Keywords:

Waraga,

Identifying Ability,

Cultural Diversity.

\section{Abstract}

This research aims to describe the enhancement of elementary school students 'ability to identify cultural diversity, as well as describe the improvement of basic skills teaching teachers through the application of Waraga media.

The research method used is a class action research conducted as many as 2 cycles. Each cycle is implemented during 2 meetings. Cycles consist of planning, acting, observing, and reflecting. The subject of the study was 28 graders of SD Negeri 2 Pecangaan Wetan in Lesson 2019/2020. The technique of data collection during the implementation of class action research using test techniques in the form of evaluation test to know the improvement of students ' ability to identify cultural diversity, and nontest technique in the form of observation of teacher teaching basic skills using observation sheet consisting of 8 observed aspects. Data analysis used is quantitative and qualitative data analysis.

The results showed that with the use of the media waraga in learning occurs increase the ability of students in identifying cultural diversity in elementary schools. Proven from the increasing percentage of the classical dictancy. Cycle I gained a percentage of $68 \%$ and cycle II gained $86 \%$. The results also showed improved teacher teaching basic skills, proven from observations that gained a score percentage of $77.3 \%$ on the I cycle and increased to $85 \%$ in cycle II.

\begin{abstract}
Abstrak
Penelitian ini bertujuan untuk mendeskripsikan peningkatan kemampuan siswa sekolah dasar dalam mengidentifikasi keragaman budaya, serta mendeskripsikan peningkatan keterampilan dasar mengajar guru melalui penerapan media waraga.

Metode penelitian yang digunakan yaitu penelitian tindakan kelas yang dilakukan sebanyak 2 siklus. Setiap siklus dilaksanakan selama 2 pertemuan. Siklus terdiri dari perencanaan, pelaksanaan tindakan, pengamatan, dan refleksi. Subjek penelitian yakni 28 siswa kelas IV SD Negeri 2 Pecangaan Wetan tahun pelajaran 2019/2020. Teknik pengumpulan data saat pelaksanaan penelitian tindakan kelas yakni menggunakan teknik tes berupa tes evaluasi untuk mengetahui peningkatan kemampuan siswa dalam mengidentifikasi keragaman budaya, dan teknik nontes berupa pengamatan keterampilan dasar mengajar guru dengan menggunakan lembar pengamatan yang terdiri dari 8 aspek yang diamati. Analisis data yang digunakan yakni analisis data kuantitatif dan kualitatif.

Hasil penelitian menunjukkan dengan digunakannya media waraga dalam pembelajaran terjadi peningkatan kemampuan siswa dalam mengidentifikasi keragaman budaya di sekolah dasar. Terbukti dari peningkatan persentase ketuntasan klasikal. Siklus I memperoleh persentase $68 \%$ dan siklus II memperoleh $86 \%$. Hasil penelitian juga menunjukkan peningkatan keterampilan dasar mengajar guru, terbukti dari hasil pengamatan yang memperoleh persentase skor $77,3 \%$ pada siklus I dan meningkat menjadi $85 \%$ pada siklus II.
\end{abstract}




\section{PENDAHULUAN}

Indonesia merupakan negara kepulauan yang mempunyai beragam budaya. Data statistik kementerian pendidikan dan kebudayaan tahun 2019 mencatat Indonesia memiliki 803 warisan budaya tak benda yang tersebar di 34 provinsi (Hadi dkk, 2019). Dalam beragam budaya, Setiadi, dkk (2012) mengartikan beragam sebagai berbagai jenis. Sedangkan budaya menurut Tylor (dalam Kistanto, 2015) diartikan sebagai satuan kompleks yang mencakup ilmu pengetahuan, kepercayaan, kesenian, adat, dan kebiasaan lainnya yang diperoleh manusia sebagai anggota masyarakat. Jadi, keragaman budaya dapat diartikan sebagai suatu kondisi dalam masyarakat di mana terdapat perbedaan dalam berbagai bidang yang mencakup ilmu pengetahuan, kepercayaan, kesenian, adat, dan kebiasaan. Keragaman budaya Indonesia terjadi dikarenakan masyarakatnya yang terdiri atas kumpulan kelompok-kelompok dengan ciri khas kesukuan (Widiastuti, 2013). Perbedaan latar belakang antar suku di Indonesia merupakan akibat dari lokalitas budaya (Ismaya dan Santoso, 2019). Sustianingsih (2018) menyatakan bahwa lokalitas budaya merupakan interaksi dinamis antara unsur statis berupa geografis setempat yang kemudian berpengaruh terhadap unsur dinamisnya berupa sosial budaya.

Kementerian pendidikan dan kebudayaan memasukan kompetensi dasar mengidentifikasi keragaman budaya dalam muatan ilmu pengetahuan sosial (IPS) kelas IV sekolah dasar. Pada dasarnya IPS di sekolah dasar merupakan muatan pelajaran yang mempelajari konsep, gejala, dan fakta sosial di masyarakat (Pratiwi dkk, 2018). Jadi, memasukan materi keragaman budaya dalam pembelajaran merupakan pencerminan IPS itu sendiri. Dalam buku siswa kelas IV sekolah dasar kompetensi dasar mengidentifikasi keragaman budaya di terapkan dengan menyajikan hasil identifikasi teks nonfiksi tentang keragaman budaya. Mudikawaty, dkk (2018) mengungkapkan bahwa nonfiksi merupakan karya yang bersifat faktual, artinya sesuai dengan fakta yang ada.

Berdasarkan hasil observasi terhadap kemampuan siswa pada muatan IPS di SD Negeri 2 Pecangaan Wetan menunjukkan nilai ulangan yang selalu rendah. Salah satu hasil ulangan harian menunjukkan persentase ketuntasan klasikal 39\%. Observasi lebih lanjut, diketahui rendahnya nilai muatan IPS siswa disebabkan karena pembelajaran monoton, belum terpusat pada siswa, serta siswa kurang tertarik dengan pembelajaran. Dalam kurikulum 2013 guru seharusnya bertindak sebagai fasilitator, namun yang ditemukan pada pembelajaran di kelas IV SD Negeri 2 Pecangaan Wetan, guru masih sebagai pusat pembelajaran. Maksud dari guru sebagai pusat pembelajaran yaitu guru aktif menerangkan sedangkan siswa hanya mendengarkan guru dan mencatat materi. kegiatan pembelajaran yang monoton tersebut tidak menumbuhkan minat siswa untuk belajar. Solusi permasalahan tersebut dapat digunakan media pembelajaran dalam proses belajar. Kemp dan Dyton (dalam Karo-karo dan Rohani, 2018) mengemukakan bahwa media dapat mengubah peran guru ke arah yang lebih positif dan produktif serta proses pembelajaran menjadi lebih jelas dan menarik. Gagne (dalam Fadhli, 2015) mengartikan media pembelajaran sebagai berbagai jenis komponen dalam lingkungan siswa yang dapat memacu siswa untuk belajar. Oleh sebab itu agar pembelajaran bervariasi guru dapat menggunakan media pembelajaran untuk proses belajar.

Media pembelajaran dapat dikembangkan dengan mengubungkan budaya sekitar atau biasa disebut dengan istilah etno (Priyani dan Nawawi, 2020). Salah satu media pembelajaran yang dapat digunakan untuk permasalahan di SD Negeri 2 Pecangaan Wetan yaitu media waraga (wayang keragaman). Selain sebagai warisan budaya, kini wayang dapat dimodifikasi sesuai kebutuhan untuk menunjang proses pembelajaran. Oktavianti dan Wiyanto (2014) mengungkapkan wayang dapat digunakan sebagai media yang edukatif, dan efektif dalam pembelajaran, dengan kemasan yang berbeda. Media waraga yang berbentuk wayang dapat menumbuhkan ketertarikan siswa untuk belajar. Sejalan dengan pendapat Saputro dan Soebijantoro (2015) yang menyatakan bahwa media pembelajaran berbentuk wayang mampu menciptakan suasana belajar yang menyenangkan dan meningkatkan semangat belajar siswa.

Media waraga (Wayang keragaman) merupakan salah satu pengembangan wayang dengan kemasan berbeda yang digunakan untuk media pembelajaran. Waraga terdiri dari Lembar Kerja Kelompok berisi teks nonfiksi mengenai suatu budaya, dan gambar budaya tersebut yang di cetak pada kertas yang tahan air, di potong sesuai bentuk gambar, kemudian ditempel pada tongkat yang terbuat dari bambu. media Waraga dibuat khusus untuk pembelajaran yang berkaitan dengan keragaman budaya. Media Waraga memuat keragaman suku, keragaman bahasa, keragaman rumah adat, dan keragaman pakaian adat. Jadi, media waraga bukanlah wayang dalam arti sebenarnya melainkan hanya 
visualisasi dari suatu budaya. Media waraga dapat dilihat pada Gambar 1.

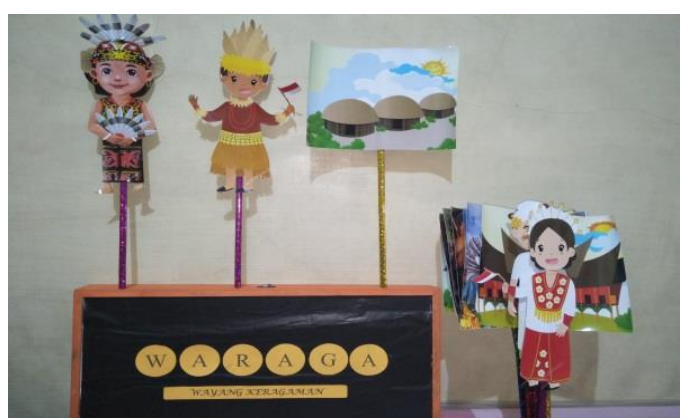

Gambar 1. Media Waraga

Sumber: Dokumentasi peneliti

Tahapan penggunaan media waraga dalam pembelajaran yaitu (1) membagi siswa ke dalam beberapa kelompok; (2) membagi media waraga pada setiap kelompok; (3) siswa secara kooperatif membaca teks nonfiksi; (4) siswa secara kooperatif menyajikan hasil identifikasi teks nonfiksi yang telah dibaca; (5) siswa memilih juru bicara perwakilan kelompok; (6) juru bicara menyampaikan hasil identifikasi dengan membawa media waraga.

Adapun penelitian ini ditujukan untuk mengetahui peningkatan keterampilan dasar mengajar guru dengan menggunakan media waraga serta peningkatan kemampuan siswa sekolah dasar dalam mengidentifikasi keragaman budaya melalui media waraga.

\section{METODE PENELITIAN}

Metode penelitian yang digunakan yaitu metode PTK (Penelitian Tindakan Kelas). PTK terdiri dari 2 siklus. Siklus PTK menurut Arikunto (2014) terdiri atas perencanaan, pelaksanaan tindakan, pengamatan, dan refleksi. Setiap siklus dilakukan sebanyak 2 kali pertemuan. Subjek penelitian yakni 28 siswa kelas IV SD Negeri 2 Pecangaan Wetan tahun pelajaran 2019/2020. Data awal diperoleh dari observasi pembelajaran di kelas IV, wawancara dengan guru kelas IV dan wawancara dengan siswa kelas IV SD Negeri 2 Pecangaan Wetan serta data dokumen siswa yang berupa nama dan nilai ulangan harian.

Teknik untuk mengumpulkan data saat pelaksanaan PTK yaitu menggunakan teknik tes dan non tes. Teknik tes menggunakan instrumen tes evaluasi di akhir siklus untuk mengetahui peningkatan kemampuan siswa dalam mengidentifikasi keragaman budaya. Teknik non tes berupa pengamatan keterampilan dasar mengajar guru selama pertemuan dengan menggunakan lembar pengamatan yang terdiri dari 8 aspek yang diamati. Analisis data yang digunakan yakni analisis data kuantitatif dan kualitatif.

Mengukur keberhasilan PTK sebagai upaya meningkatkan kemampuan siswa sekolah dasar dalam mengidentifikasi keragaman budaya, dan meningkatkan keterampilan dasar mengajar digunakan batasan indikator keberhasilan. Adapun indikator keberhasilan yang digunakan yaitu: (1) Keterampilan dasar mengajar guru memperoleh persentase skor minimal 60\%; (2) Hasil tes evaluasi mencapai ketuntasan setiap individu minimal 70, serta persentase ketuntasan klasikal mencapai minimal $70 \%$.

\section{HASIL DAN PEMBAHASAN}

Penelitian tindakan kelas dengan menggunakan media waraga dilaksanakan sebanyak 2 siklus. Siklus I dilaksanakan pada tanggal 26-27 Februari 2020. Siklus II dilaksanakan pada tanggal 28-29 Februari 2020.

Sebelum pelaksanaan penelitian tindakan kelas dilaksanakan kegiatan prasiklus. Prasiklus dimaksudkan untuk mencari tahu keadaan sebenarnya pada subjek penelitian. Prasiklus berupa observasi dan wawancara terhadap subjek penelitian. Hasil observasi dan wawancara, ditemukan permasalahan di kelas IV SD Negeri 2 Pecangaan Wetan yaitu rendahnya nilai muatan IPS siswa, pembelajaran monoton, belum terpusat pada siswa, serta siswa kurang tertarik dengan pembelajaran. Nilai ulangan harian muatan IPS menunjukkan terdapat 11 siswa tuntas dan 17 siswa yang tidak tuntas. Persentase ketuntasan klasikal nilai ulangan harian muatan IPS hanya sebesar $39 \%$.

Data hasil pengamatan keterampilan dasar mengajar guru dalam pembelajaran yang menerapkan media waraga di kelas IV SD Negeri 2 Pecangaan Wetan dapat dilihat pada Tabel 1 berikut.

Tabel 1. Rekapitulasi Nilai Keterampilan Dasar Mengajar Guru Siklus I-II

\begin{tabular}{cc}
\hline Pelaksanaan & Persentase Skor \\
\hline Siklus I & $77,3 \%$ \\
Siklus II & $85 \%$ \\
\hline
\end{tabular}

Dari Tabel 1 dapat diketahui bahwa dengan penggunaan media pembelajaran waraga terjadi peningkatan keterampilan dasar mengajar guru SD Negeri 2 Pecangaan Wetan. Persentase skor yang diperoleh pada siklus I sebesar 77,3\% dan meningkat menjadi $85 \%$ pada siklus II.

Keterampilan dasar mengajar yaitu keterampilan yang berkaitan dengan semua aspek kemampuan guru dalam menjalankan tugasnya sebagai guru (Wahyulestari, 2018). ada beberapa aspek keterampilan dasar mengajar. 
Turney (dalam Majid, 2013) mengungkapkan ada 8 aspek keterampilan dasar mengajar yang harus dimiliki guru, yaitu: (1) keterampilan membuka dan menutup pelajaran; (2) keterampilan bertanya; (3) keterampilan memberi penguatan; (4) keterampilan mengadakan variasi; (5) keterampilan menjelaskan; (6) keterampilan membimbing diskusi kelompok kecil; (7) keterampilan mengajar kelompok kecil dan mengajar perseorangan; (8) keterampilan mengelola kelas. Dengan penggunaan media waraga dalam pembelajaran mengharuskan guru untuk mengimplementasikan keterampilan dasar mengajar yang dimiliki. Sehingga guru yang awalnya hanya menggunakan beberapa aspek keterampilan menjadi menggunakan semua aspek keterampilan dasar mengajar dengan lebih baik lagi. Sejalan dengan Kemp dan Dyton (dalam Karo-karo dan Rohani, 2018) mengemukakan bahwa media dapat mengubah peran guru ke arah yang lebih positif dan produktif.

Selain peningkatan keterampilan dasar mengajar guru, peningkatan juga terjadi pada hasil tes evaluasi siswa dengan soal tes mengenai identifikasi keragaman budaya. Keragaman budaya dalam soal tes evaluasi memiliki batasan tertentu. Batasan tersebut yaitu soal tes hanya mengenai keragaman suku, keragaman bahasa, keragaman rumah adat, dan keragaman pakaian adat. Rekapitulasi persentase ketuntasan klasikal hasil tes evaluasi setiap siklus disajikan pada Tabel 2.

Tabel 2. Rekapitulasi Hasil Tes Evaluasi Siklus I-II

\begin{tabular}{cc}
\hline Pelaksanaan & Persentase Ketuntasan Klasikal \\
\hline Siklus I & $68 \%$ \\
Siklus II & $86 \%$ \\
\hline
\end{tabular}

Berdasarkan Tabel 2 diketahui bahwa terjadi peningkatan dari siklus I ke siklus II. Pada siklus I persentase ketuntasan klasikal yang diperoleh sebesar $68 \%$ meningkat sebesar $18 \%$ menjadi $86 \%$ pada siklus II. Peningkatan persentase ketuntasan klasikal berarti terjadi peningkatan kemampuan siswa dalam mengidentifikasi keragaman budaya di sekolah dasar. Peningkatan ini tentunya terjadi karena penggunaan media waraga pembelajaran Media waraga memberikan gambaran konkret mengenai materi sehingga siswa mudah memahami materi. Sejalan dengan Sadiman dkk (2011) yang mengemukakan bahwa media gambar sifatnya konkret yaitu gambar lebih realistis menunjukkan pokok masalah dibandingkan media verbal.
Media waraga melatih siswa mengenai beberapa keterampilan berbahasa. Menurut Tarigan (2008) keterampilan berbahasa terdiri dari 4 segi yaitu keterampilan menyimak, keterampilan berbicara, keterampilan membaca, dan keterampilan menulis. Ada dua keterampilan berbahasa yang diimplementasikan pada saat pembelajaran menggunakan media waraga.

Salah satu keterampilan berbicara yang ditemukan dalam pembelajaran menggunakan media waraga adalah keterampilan membaca. Aida dkk (2018) menyatakan bahwa membaca yakni suatu kegiatan untuk informasi yang disampaikan oleh penulis dalam bahasa tulisan. Salah satu bagian dari pembelajaran menggunakan media waraga adalah diskusi kelompok. Pada saat diskusi, siswa diberi lembar kerja kelompok yang berisi teks nonfiksi mengenai kebudayaan sesuai gambar yang didapat. Siswa membutuhkan keterampilan membaca untuk mengidentifikasi isi teks nonfiksi dalam lembar kerja kelompok. Permasalahan yang ditemukan yaitu rendahnya penguasaan kosakata Bahasa Indonesia oleh beberapa siswa sehingga siswa tidak memahami maksud dari kalimat dalam teks. Pramesti (2015) mengungkapkan faktor penyebab rendahnya penguasaan kosakata Bahasa Indonesia dikarenakan siswa kurang aktif berkomunikasi dengan menggunakan Bahasa Indonesia. Siswa lebih sering menggunakan bahasa daerah untuk berkomunikasi. Namun, dengan diskusi kelompok siswa saling memberitahu apa yang diketahui kepada anggota kelompoknya. Sejalan dengan Ermi (2015) yang menyatakan bahwa diskusi kelompok merupakan metode pembelajaran yang di dalamnya terdapat percakapan antar individu dalam kelompok yang dihadapkan oleh suatu permasalahan sehingga mereka dapat bertukar pikiran.

Keterampilan berbahasa yang dapat ditemukan lagi di pembelajaran dengan menggunakan media waraga yaitu keterampilan menyimak. Keterampilan menyimak yaitu kemampuan seseorang dalam mendengarkan dengan penuh pemahaman, perhatian, dan apresiasi (Tarigan, 2008). Keterampilan menyimak dapat ditemukan pada tahap mendengarkan juru bicara menyampaikan hasil diskusi. Permasalahan yang ditemukan yaitu kemampuan pendengaran antar siswa yang berbeda-beda. Pada saat penyampaian hasil diskusi siswa membutuhkan kemampuan mendengar untuk menyimak hasil diskusi agar siswa mengetahui materi. Untuk mengatasi permasalahan keterampilan menyimak individu siswa yang berbeda-beda, maka dengan maksimal guru mengelola kelas agar kondusif 
pada saat penyampaian hasil diskusi. Dengan situasi kelas yang kondusif siswa yang berperan sebagai pendengar lebih mudah dalam menyimak hasil diskusi yang disampaikan. Sejalan dengan Arianti (2017) yang menyatakan bahwa kelas yang kondusif memudahkan siswa menerima materi.

Penggunaan media berbasis budaya membuat pembelajaran lebih menarik (Juliarto dkk, 2020). Gambar pada media waraga terdiri dari berbagai macam gambar kebudayaan. Hasil penelitian menunjukkan dengan penerapan media waraga antusias siswa begitu besar saat guru menyajikan media waraga yang berbeda-beda setiap pertemuan sehingga siswa tertarik untuk belajar. Sependapat dengan Hilmi (2016) bahwa penggunaan gambar yang berwarna-warni membuat siswa tertarik dan meningkatkan minat belajar sehingga siswa akan berkonsentrasi pada pembelajaran. Ardianti, dkk (2019) berpendapat bahwa pembelajaran dengan mengkaitkan budaya membuat siswa lebih tertarik dalam pembeljaran.

Penelitian yang dilakukan mempunyai persamaan dan perbedaan dengan Oktavianti dan Wiyanto (2014), penelitian Saputro dan Soebijantoro (2015), penelitian Pratiwi (2018), penelitian Sumaryanti dkk (2018), dan penelitian Yulistyana (2016). Persamaan yang dimaksud yaitu Penggunaan wayang dengan kemasan yang berbeda menjadi media pembelajaran.

\section{SIMPULAN}

Simpulan yang didapat yaitu penerapan media waraga dapat meningkatkan kemampuan siswa dalam mengidentifikasi keragaman budaya di sekolah dasar, terbukti dari peningkatan persentase ketuntasan klasikal. Pada siklus I memperoleh persentase ketuntasan klasikal sebesar $68 \%$ dan meningkat menjadi $86 \%$ pada siklus II. Peningkatan juga terjadi pada keterampilan guru akibat dari penerapan media waraga, terbukti melalui persentase skor hasil pengamatan yang meningkat dari $77,3 \%$ pada siklus I menjadi $85 \%$ pada siklus II.

\section{DAFTAR PUSTAKA}

Aida, Siti., Suprapti, Ani., dan Nasirun, M. 2018. Meningkatkan Keterampilan Membaca Awal Melalui Metode Struktural Analitik Sintetik dengan Menggunakan Media Audio Visual. Jurnal Ilmiah Potensia, 3 (2): 56-63.

Ardianti, S. D., Wanabuliandari, S., \& Kanzunnudin, M. 2019. Implementasi Pembelajaran Berbasis Ethno-
Edutainment Untuk Meningkatkan Karakter Cinta Tanah Air Siswa Sekolah Dasar. Refleksi Edukatika: Jurnal Ilmiah Kependidikan, 9(2).

Arianti. 2017. Urgensi Lingkungan Belajar yang Kondusif Dalam Mendorong Siswa Belajar Aktif. Didaktika Jurnal Kependidikan, 11 (1): 41-62.

Arikunto, Suharsimi. 2014. Prosedur Penelitian (Suatu Pendekatan Praktik). Jakarta: PT. Rineka Cipta.

Ermi, Netti. 2015. Penggunaan Metode Diskusi untuk Meningkatkan Hasil Belajar Materi Perubahan Sosial pada Siswa Kelas XII SMA Negeri 4 Pekanbaru. Jurnal Sorot, 10 (2): $155-168$.

Fadhli, Muhibuddin. 2015. Pengembangan Media Pembelajaran Berbasis Video Kelas IV Sekolah Dasar. Jurnal Dimensi Pendidikan dan Pembelajaran, 3 (1):2429.

Hadi, Dwi Winanto et al (Ed). 2019. Statistik Kebudayaan 2019. Jakarta: PDSPK Kemdikbud.

Hilmi. 2016. Efektivitas Penggunaan Media Gambar dalam Pembelajaran Bahasa Arab. Lantanida Journal, 4 (2): 128-135.

Ismaya, E. A., \& Santoso, S. (2019). Tradisi Dandangan Sebagai Kajian Pembelajaran dalam Mendukung Pencapaian Visi Universitas Kebudayaan (Studi Pada Mata Kuliah Konsep Ilmu Pengetahuan Sosial). Refleksi Edukatika: Jurnal Ilmiah Kependidikan, 10(1), 128-137.

Juliarto, F. F., Oktavianti, I., \& Purbasari, I. 2020. Implementasi Media Utangklek Terhadap Peningkatan Hasil Belajar Siswa Sekolah Dasar. WASIS: Jurnal Ilmiah Pendidikan, 1(1), 36-43.

Karo-Karo, Isran Rasyid., dan Rohani. 2018. Manfaat Media dalam Pembelajaran. Axiom Jurnal Pendidikan dan Matematika, 7 (1): 91-96.

Kistanto, Nurdien Harry. 2015. Tentang Konsep Kebudayaan. Jurnal Sabda, 10 (2).

Majid, Abdul. 2013. Strategi Pembelajaran. Bandung: PT. Remaja Rosdakarya. 
Mudikawaty, Meity., Meisawati, Melli., dan Nurdiana, Ari. 2018. Super Complete Kelas 4,5,6 SD/MI. Depok: Magenta Media.

Oktavianti, Rizki., dan Wiyanto, Agus. 2014. Pengembangan Media Gayanghetum (Gambar Wayang Hewan dan Tumbuhan) dalam Pembelajaran Tematik Terintegritas Kelas IV SD. Mimbar Sekolah Dasar, 1 (1): 65-70.

Pramesti, Utami Dewi. 2015. Peningkatan Penguasaan Kosakata Bahasa Indonesia dalam Keterampilan Membaca Melalui Teka-teki Silang. Jurnal Puitika, 11 (1): 82-93.

Pratiwi, Cerianing Putri. 2018. Penerapam Wayang (Wayang Karakter) untuk Menumbuhkan Nilai Religius pada Pembelajaran Menyimak Siswa Kelas I Sekolah Dasar. Studi Kependidikan dan Keislaman, 8 (1): 65-76.

Pratiwi, Ika Ari., Ardianti, Sekar Dwi., dan Kanzunnudin, Moh. 2018. Peningkatan Kemampuan Kerjasama Melalui Model Project Based Learning (PBL) Berbantuan Metode Edutainment pada Mata Pelajaran Ilmu Pengetahuan Sosial. Jurnal Refleksi Edukatika, 8 (2): 177-182

Priyani, N. E., \& Nawawi, N. 2020. Pembelajaran IPA Berbasis Ethno-Stem Berbantu Mikroskop Digital Untuk Meningkatkan Keterampilan Proses Sains Di Sekolah Perbatasan. WASIS: Jurnal Ilmiah Pendidikan, 1(2), 99-104.

Sadiman, Arief S dkk. 2011. Media Pendidikan. Jakarta: Rajawali Pers.

Saputro, Oktavianto Nugroho., dan Soebijantoro. 2015. Pengembangan Wedus Gembel (Wayang Kardus Gembira dan Belajar) sebagai Media Membangun Jiwa Nasionalisme Sejak Dini pada Siswa TKK Santo Yusuf Kota Madiun. Jurnal Agastya, 5 (1): 99-117.

Setiadi, Elly M., Hakam, Abdul Kama., dan Effendi, Ridwan. 2012. Ilmu Sosial dan Budaya Dasar. Jakarta: Kencana Prenadamedia Group.
Sumaryanti, Eka., Sabri, Tahmid., dan Rosnita. 2018. Penggunaan Media Wayang pada Pembelajaran Tematik untuk Meningkatkan Hasil Belajar di Sekolah Dasar. Jurnal Pendidikan dan Pembelajaran Khatulistiwa, 7 (3): 1-9.

Sustianingsih, Hermini., Farabi, Nadia., Paramasatya, Satwika., dan Puspapertiwi, Sheiffi. 2018. Memperkuat Lokalitas Kota Semarang di Era Globalisasi melalui Diplomasi Lokal. Global \& Strategis, 12 (1): 1-15.

Tarigan, Henry Guntur. 2008. Menyimak sebagai Suatu Keterampilan Berbahasa. Bandung: Penerbit Angkasa Bandung.

Wahyulestari, Mas Roro Diah. 2018. Keterampilan Dasar Mengajar di Sekolah Dasar. Membangun Sinergitas dalam Penguatan Pendidikan Karakter pada Era IR 4.0. Jakarta: Universitas Muhammadiyah Jakarta.

Widiastuti. 2013. Analisis SWOT Keragaman Budaya Indonesia. Jurnal Ilmiah Widya, 1 (1): 8-14.

Yulistyana, Naili Vidya. 2016. Pengembangan Media Pembelajaran Wayang Cucok untuk Meningkatkan Kemahiran Kalam Pada Siswa Kelas XI MAN 1 Jepara (Tesis). Yogyakarta: Program Pascasarjana UIN Sunan Kalijaga. 